\title{
Biological Activity of Harpin Produced by Pantoea stewartii subsp. stewartii
}

\author{
Musharaf Ahmad, ${ }^{1}$ Doris R. Majerczak, ${ }^{1}$ Sharon Pike, ${ }^{2}$ Mary Elizabeth Hoyos, ${ }^{2}$ Anton Novacky, ${ }^{2}$ \\ and David L. Coplin ${ }^{1}$ \\ ${ }^{1}$ Department of Plant Pathology, The Ohio State University, Columbus 43210-1087, U.S.A.; ${ }^{2}$ Department \\ of Plant Pathology, University of Missouri, Columbia 65211, U.S.A. \\ Submitted 6 November 2000; Accepted 25 June 2001.
}

\begin{abstract}
Pantoea stewartii subsp. stewartii causes Stewart's wilt of sweet corn. A hypersensitive response and pathogenicity (Hrp) secretion system is needed to produce water-soaking and wilting symptoms in corn and to cause a hypersensitive response (HR) in tobacco. Sequencing of the hrp cluster revealed a putative harpin gene, $h r p N$. The product of this gene was overexpressed in Escherichia coli and shown to elicit the HR in tobacco and systemic resistance in radishes. The protein was designated $\mathrm{HrpN}_{\text {Pnss }}$. Like other harpins, it was heat stable and protease sensitive, although it was three- to fourfold less active biologically than $\mathrm{Er}$ winia amylovora harpin. We used antibodies to purified $\mathrm{HrpN}_{\text {Pnss }}$ to verify that $h r p N$ mutants could not produce harpin. This protein was secreted into the culture supernatant and was produced by strains of $P$. stewartii subsp. indologenes. In order to determine the importance of $\operatorname{HrpN}_{\text {Pnss }}$ in pathogenesis on sweet corn, three $h r p N:: \operatorname{Tn} 5$ mutants were compared with the wild-type strain with $50 \%$ effective dose, disease severity, response time, and growth rate in planta as parameters. In all tests, $\mathrm{HrpN}_{\text {Pnss }}$ was not required for infection, growth, or virulence in corn or endophytic growth in related grasses.
\end{abstract}

Additional keywords: Erwinia stewartii, type III secretion.

The ability of plant-pathogenic bacteria to elicit the hypersensitive response (HR) in resistant or nonhosts is correlated with their ability to cause disease in susceptible hosts. Both of these capabilities are determined by hypersensitive response and pathogenicity ( $h r p$ ) genes (Lindgren 1997), which encode components of a protein secretion pathway, regulatory factors, and a number of secreted effector proteins (Alfano and Collmer 1997; He 1998; Mudgett and Staskawicz 1998). hrp genes are conserved in various Erwinia, Pantoea, Pseudomonas, Xanthomonas, and Ralstonia species that are pathogenic on plants. Sequence similarities between hrp genes and genes for type III secretion systems in mammalian pathogens revealed that they are closely related. In animal pathogens, type III secretion systems translocate effector proteins directly into host cells. By analogy, Hrp secretion systems may likewise inject pathogenicity and Avr proteins directly into plant cells.

Corresponding author: D. L. Coplin; E-mail: coplin.3@osu.edu

Nucleotide and/or amino acid accession sequence data is in the GenBank database, accession no. AF282857.
Under certain conditions, phytopathogenic bacteria can secrete Avr and Hrp outer (Hops) proteins into culture supernatants (Gueneron et al. 2000; Rossier et al. 1999; Van Dijk et al. 1999), but there is only indirect evidence that these proteins are translocated into plant cells via the Hrp pathway (Mudgett and Staskawicz 1999).

In Erwinia and Pantoea spp., one or two genes in each hrp cluster encode a heat-stable, glycine-rich, extracellular protein that can elicit the HR when purified and applied externally to nonhost plant cells. These proteins have been termed harpins. The first harpin was isolated from Erwinia amylovora (Wei et al. 1992). A cell-free elicitor preparation (CFEP) obtained after boiling and centrifuging a cell sonicate gave a strong HR when infiltrated into tobacco. The activity of the CFEP was associated with a $44-\mathrm{kDa}$ protein, which was encoded by the $h r p N$ gene and called harpin ${ }_{\mathrm{Ea}}$ (or $\mathrm{HrpN}_{\mathrm{Ea}}$ ). In strain Ea321, $\mathrm{HrpN}_{\mathrm{Ea}}$ is needed for the elicitation of the HR on tobacco and for pathogenicity on apples and pears (Wei and Beer 1993; Wei et al. 1992), thus it was initially proposed that $\mathrm{HrpN}_{\mathrm{Ea}}$ was the main pathogenicity factor of E. amylovora. Barny (1995), however, later found that $h r p N$ mutants of strain CFPB1430 retained weak but significant pathogenicity and could still elicit a variable HR in tobacco. She attributed these results to different assay conditions and concluded that other necessary effector proteins such as DspE (Bogdanove et al. 1998a; Bogdanove et al. 1998b; Gaudriault et al. 1997) also must be secreted by the Hrp system.

Erwinia chrysanthemi, a wide host-range pathogen that rapidly kills and macerates host tissues, also produces a harpin. Although pectic enzyme production in wild-type bacteria masks the HR, $\triangle$ pelABCE Out $^{-}$mutants of Erwinia chrysanthemi elicit rapid necrosis in tobacco leaves. $h r p N_{E c h}$ is required for HR elicitation in tobacco and contributes in a minor way to infectivity on witloof chicory (Bauer et al. 1994; Bauer et al. 1995). In Erwinia carotovora subsp. carotovora, rmsA mutants have been shown to produce a related harpin that is needed for HR elicitation, although its importance in pathogenicity has not been determined (Cui et al. 1996; Mukherjee et al. 1997). Most recently, sequence analysis of the hrp cluster of the gall-forming bacterium Erwinia herbicola (syn. Pantoea agglomerans) pv. gypsophilae also has revealed a $h r p N$ gene that encodes an active harpin (Mor et al. 2001). Transposon mutagenesis of this gene did not affect pathogenicity but reduced HR elicitation. A second type of harpin, termed HrpW, also is produced by E. amylovora (Gaudriault et al. 1998; Kim and Beer 1998). The $\mathrm{N}$ terminus of HrpW 
shares properties of harpins and is capable of HR elicitation. The $\mathrm{C}$ terminus is related to pectic lyases but lacks enzyme activity. HrpW does not appear to be necessary for pathogenicity or HR elicitation.

In Pseudomonas syringae pathovars (He et al. 1993), a harpin is encoded by hrpZ. Deletion of hrpZ in $P$. syringae pv. syringae strain $\mathrm{B} 728 \mathrm{~A}$ affects virulence on beans only when the bacteria are inoculated onto the surface of leaves (Loniello et al. 1995). In addition to HrpZ, these pathovars also produce a HrpW class harpin (Charkowski et al. 1998) and an Avr-like protein, HopPsyA (HrmA) (Van Dijk et al. 1999). The latter appears to be an important elicitor when wild-type bacteria are infiltrated into tobacco. A similar extracellular HR-elicitor protein, PopA, is secreted by Ralstonia solanacearum. popA mutants are fully pathogenic on tomatoes and susceptible petunia lines (Arlat et al. 1994). An open reading frame (ORF), hpal, is linked to the hrp cluster in Xanthomonas oryzae pv. oryzae and encodes a harpin-like protein with $26 \%$ glycine (Zhu et al. 2000). Mutation of hpal results in the reduction of water-soaking ability.

Harpins exhibit little or no amino acid sequence similarity but have several physical and chemical properties in common. They are protease sensitive, glycine rich, heat stable, acidic, do not contain cysteine, and lack a N-terminal signal sequence (Arlat et al. 1994; He et al. 1993). The elicitor activity does not seem to be confined to any one domain of the protein because various fragments retain activity (Alfano et al. 1996; Arlat et al. 1994; Laby and Beer 1995). E. amylovora secretes $\mathrm{HrpN}_{\mathrm{Ea}}$ in apple seedlings, but the bulk of the secreted protein appears to remain attached to the bacterial cell wall (Perino et al. 1999) and was not observed in association with the host cell wall. Brown et al. (2001) used immunogold labeling to study the release of $P$. syringae pv. tomato $\mathrm{HrpZ}_{\mathrm{Pst}}$ in vitro and in Arabidopsis. In culture, $\mathrm{HrpZ}_{\mathrm{Pst}}$ was first seen at the base of pili and then became associated with a matrix coating the length of the pilus. In planta, they observed it in the bacterial cytoplasm and inner and outer membranes where labeling extended into the intercellular spaces and onto pili crossing the plant cell wall. In terms of eliciting the HR, the action site for harpin appears to be on the plant cell surface because transgenic Nicotiana benthamiana plants expressing $\mathrm{HrpZ}_{\mathrm{Psph}}$ in the cytoplasm are not affected adversely (Tampakaki and Panopoulos 2000). When a signal peptide is added to the $\mathrm{N}$ terminus of the protein so that it is secreted, expression of $\mathrm{HrpZ}_{\mathrm{Psph}}$ induces necrosis. A protein with a signal peptide that is correlated with harpin sensitivity of pepper tissue has been proposed to be a harpin receptor (Chen et al. 2000). Purified $\mathrm{HrpN}_{\mathrm{Ea}}$ has been shown to depolarize plant cell membranes in cell suspension cultures (Popham et al. 1995) and leaves (Pike et al. 1998), and $\mathrm{HrpZ}_{\mathrm{Psph}}$ forms ion-conducting pores in lipid bilayers (Lee et al. 2001) so that pathogens may use them to damage cell membranes in order to release nutrients from host cells early in infection. Alternatively, harpins may aid in the translocation of some Hop and Avr proteins across the plant plasma membrane. The finding that they appear only to have minor effects on virulence, however, means that they may be redundant or this function is optional.

Pantoea stewartii subsp. stewartii (syn. Erwinia stewartii) has a $h r p-w t s$ gene cluster that is required for lesion formation and wilting on corn (Coplin et al. 1992a; Coplin et al. 1992b). As reported in an accompanying paper (Frederick et al. 2001), this cluster is $28 \mathrm{~kb}$ and consists of eight complementation groups. The genes in this cluster have sequence homology with hrp genes of E. amylovora and E. herbicola pv. gypsophilae and are very similar in genetic organization and regulation. The $h r p N_{P n s s}$ gene is located between the $h r p C$ and $w t s E$ operons and is regulated by HrpS (Frederick et al. 2001). This ORF is predicted to encode a 382 amino acid protein that has 70,62, 45, and 7\% amino acid identity to harpins from $E$. herbicola pv. gypsophilae, E. amylovora, E. chrysanthemi, and $P$. syringae pv. syringae, respectively. Wild-type $P$. stewartii subsp. stewartii does not cause the HR in tobacco under normal assay conditions when grown on rich media and previously has been considered to be an exception to the rule that gram-negative phytopathogenic bacteria can cause a HR. In this study, however, we demonstrate that $P$. stewartii subsp. stewartii can incite a $\mathrm{HrpN}_{\text {Pnss }}$-dependent $\mathrm{HR}$ on tobacco and Datura spp. when bacteria overexpress hrpS or are preinduced in a medium that mimics some conditions in the plant apoplast. DM760, the single $h r p N:: \operatorname{Tn} 5$ mutant constructed in the accompanying paper (Frederick et al. 2001), was virulent on corn seedlings in water-soaking assays and did not cause a HR on tobacco. In this study, we report the characterization of $\mathrm{HrpN}_{\text {Pnss }}$, its biological activity and a quantitative assessment of its importance in the pathogenicity of $P$. stewartii subsp. stewartii on sweet corn (Zea mays cv. saccharata [Sturtev.] Bailey), and in the ability of P. stewartii subsp. stewartii to multiply in various graminaceous hosts.

\section{RESULTS}

\section{P. stewartii subsp. stewartii cells and extracts can elicit the HR in tobacco.}

P. stewartii subsp. stewartii grown on rich media such as Luria-Bertani (LB) or Casamino Acids-peptone-glucose agar or broth did not cause a HR in tobacco under typical assay conditions. Bacterial populations in infiltrated tobacco leaves, however, remained above $5 \times 10^{7} \mathrm{CFU} / \mathrm{g}$ or at least $12 \mathrm{~h}$, which normally is considered a sufficient cell concentration and time period for most incompatible bacteria to elicit the HR. We hypothesized that the failure of $P$. stewartii subsp. stewartii to elicit the HR might be the result of poor expression of the hrp genes in tobacco or low activity of the elicitor protein(s).

Two approaches were used to increase hrp gene expression and elicitor production. The first involved growing cells in a semi-defined medium that we developed to maximize hrpJ::lacZ expression in strain DM711. This inducing medium (IM) was low in inorganic nitrogen and phosphate, contained sucrose and Casamino Acids, and was acidic ( $\mathrm{pH}$ 5.5). When grown in IM, wild-type strain DC283 frequently gave a typical HR, although this reaction varied from leaf to leaf and plant to plant and ranged from confluent to patchy necrotic areas within the infiltrated tissue. In the second approach, plasmids pES411 and pRF205 were introduced into DC283 to increase expression of the hrp genes. pES411 provided extra copies of the entire $h r p$ regulatory region ( $h r p S-h r p X Y-h r p L)$, whereas pRF205 only contained $h r p S$ driven by a strong lac $Z$ promoter. The transconjugants gave a strong, consistent HR response in tobacco, which was visible as early as $18 \mathrm{~h}$ after infiltration with $10^{8} \mathrm{CFU} / \mathrm{ml}$. This occurred even when bacteria were grown on rich medium such as LB agar. This HR was much stronger than that observed for DC283 grown in IM. 
CFEPs also were active in inducing the HR in tobacco. CFEPs were prepared according to the procedure used for purification of the E. amylovora harpin (Wei et al. 1992). DC283 was grown in IM medium $\left(\mathrm{A}_{540}=0.8\right)$, sonicated in the presence of phenylmethylsulfonyl fluoride (PMSF), boiled, and centrifuged to obtain the soluble fraction. This extract was highly effective in inducing a HR within $18 \mathrm{~h}$. CFEPs also elicited a rapid HR in leaves of 2month-old Datura stramonium L. plants. The elicitor activity was heat stable but appeared to be protease sensitive because we were unable to obtain active preparations without the use of the protease inhibitor PMSF. This suggests that the active elicitor was a polypeptide. CFEPs prepared from $h r p N$ mutant DM760(pRF205) and various $h r p$ regulatory mutants were inactive, but those from secretion mutants were active in eliciting the HR in tobacco (Frederick et al. 2001).

\section{Production of HrpN $\mathbf{N}_{\text {Pnss }}$ in Escherichia coli.}

To confirm the protein product of the hrpN ORF and to prepare purified $\mathrm{HrpN}_{\text {Pnss }}$, we used an E. coli $\mathrm{T} 7$ expression system. A 1.8-kb HindIII fragment containing $h r p N$ was cloned

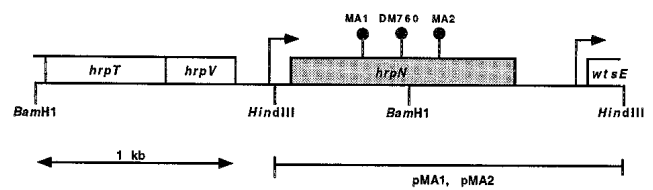

Fig. 1. Genetic map of the hrpN region within the Pantoea stewartii subsp. stewartii hrp-wts cluster that was cloned into pDM2530. Boxes delimit the $h r p T, h r p V, h r p N$, and $w t s E$ open reading frames (ORFs), and arrows indicate HrpL-dependent promoters. Transcription of all ORFs is from left to right. Solid circles mark the positions of Tn5 insertions in mutants MA1, DM760, and MA2. Insert cloned into pMA1 and pMA2 is shown below the line. into vectors pBluescript SK and pT7-7 behind the T7 promoters (Fig. 1). These clones, designated pMA1 and pMA2, respectively, were used to overexpress $\mathrm{HrpN}_{\text {Pnss }}$ in $E$. coli BL21(DE3) (Studier and Moffatt 1986). T7 polymerase was induced in BL21 by isopropyl- $\beta$-D-thiogalactopyranoside (IPTG). CFEPs were then prepared and analyzed by sodium dodecyl sulfate-polyacrylamide gel electrophoresis (SDSPAGE). Prominent 43-kDa proteins were present in extracts from strains with pMA1 or pMA2, which co-migrated with authentic $\mathrm{HrpN}_{\mathrm{Ea}}$. The estimated molecular mass of the $P$. stewartii subsp. stewartii protein, as determined by SDSPAGE, was $43 \mathrm{kDa}$ (Fig. 2). This is slightly higher than the value predicted from the sequence data, which was $39.5 \mathrm{kDa}$. E. amylovora, E. chrysanthemi, and $P$. syringae pv. syringae harpins similarly have been reported to migrate slower than expected in SDS-PAGE gels (Bauer et al. 1995; He et al. 1993; Wei et al. 1992).

\section{Secretion and biological activity of $\mathbf{H r p N _ { \text { Pnss } }}$.}

Electroelution-purified, acetone-precipitated $\mathrm{HrpN}_{\text {Pnss }}$ was produced in BL21(DE3), purified by SDS-PAGE (12\% gels), electroeluted, and precipitated with acetone. The protein was 85 to $90 \%$ homogeneous in Coomassie blue-stained gels (Fig. 2 , lane 2) and used to raise antibodies in rabbits. The resulting antiserum reacted with the $43-\mathrm{kDa}^{\mathrm{HrpN}} \mathrm{N}_{\text {Pnss }}$ band in Western blots from wild-type strain DC283 but did not react with any proteins in extracts from a $\Delta h r p-w t s$ mutant, DM3020 (Fig. 2), or DM760 hrpN::Tn5.

To determine whether $\mathrm{HrpN}_{\text {Pnss }}$ was secreted into the supernatant, DC283(pRF205) and DM756(pRF205) hrcC240::Tn5 were grown overnight in $\mathrm{LB}$ at $28^{\circ} \mathrm{C}$ and the supernatants were concentrated by trichloroacetic acid (TCA) precipitation. $\mathrm{HrpN}_{\text {Pnss }}$ was detected in the supernatant of the wild-type strain but was barely detectable in the supernatant of the $h r c C$

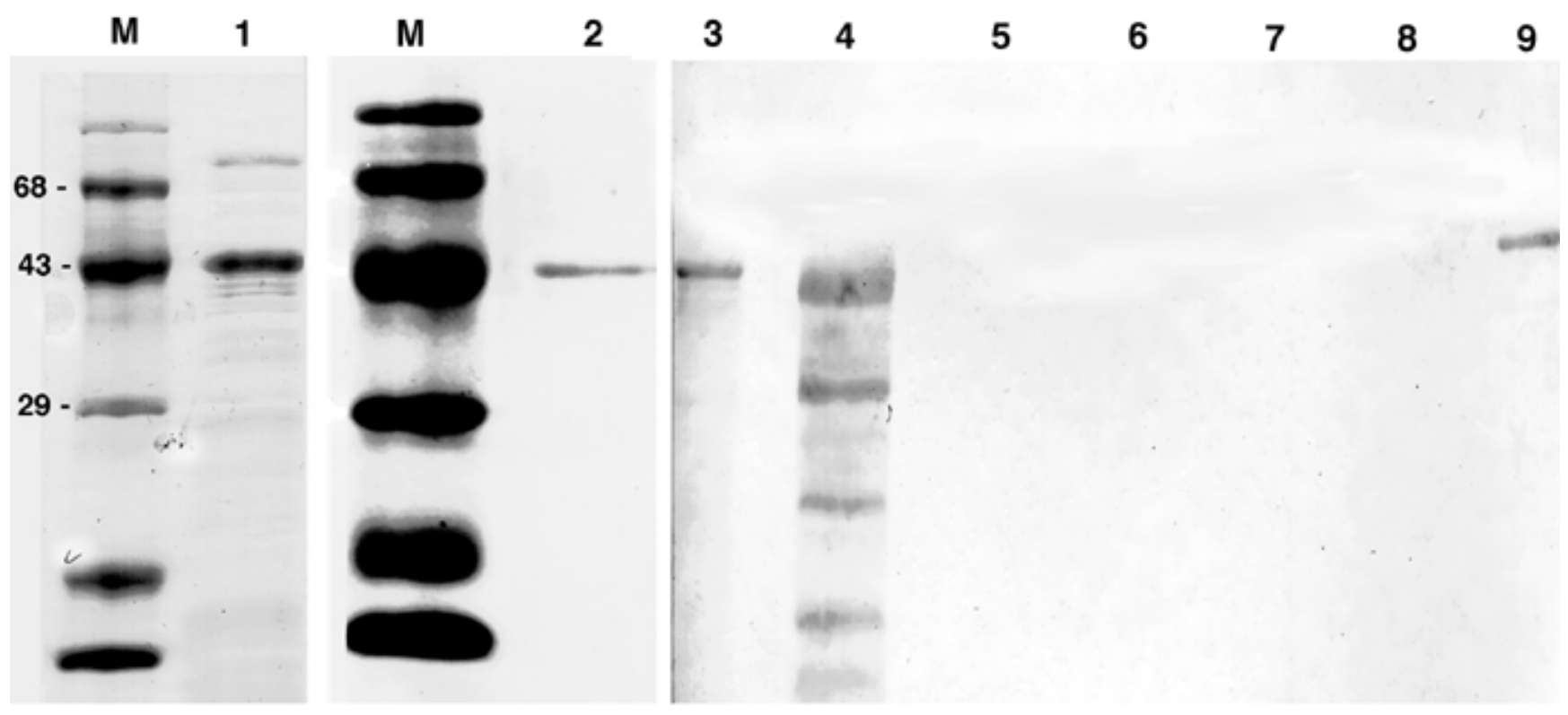

Fig. 2. Polyacrylamide gel electrophoresis (PAGE) and Western blots of cell-free elicitor preparations (CFEPs) and purified harpins. Lanes M, 1, and 2: Stained with Coomassie brilliant blue. Lane M: Molecular mass markers (\#6001LA; Life Technologies Gaithersburg, MD, U.S.A.); lane 1: Escherichia

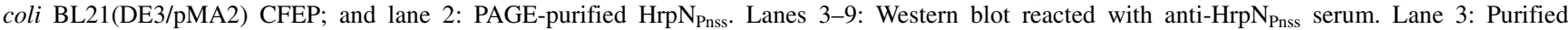
$\mathrm{HrpN}_{\text {Pnss }}$; lane 4: DC283(pRF205) wild-type CFEP; lane 5: MA1(pRF205) hrpN123::Tn5 CFEP; lane 6: MA2(pRF205) hrpN254::Tn5 CFEP; lane 7: DM760(pRF205) hrpN189::Tn5 CFEP; lane 8: DM3020(pRF205) $\Delta h r p$ CFEP; and lane 9: purified $\mathrm{HrpN}_{\mathrm{Ea}}$ 
secretion mutant (Fig. 3). The relative amounts of harpin in the supernatants and cell pellets were determined by scanning densitometry of the Western blots. About $2.4 \%$ of the total $\mathrm{HrpN}_{\text {Pnss }}$ was present in the supernatant of the wild-type strain, but only $0.04 \%$ was present in the supernatant from the $h r c C$ mutant. This experiment was repeated with similar results. To control for cell lysis, which may have been responsible for the very low amount of harpin released by the $h r c C$ mutant, we developed Western blots with antiserum to $E$. coli AraB, a cytoplasmic enzyme. In $E$. coli, this antiserum crossreacts strongly with a $45-\mathrm{kDa}$ cytoplasmic protein known as "Band X" (De Gier et al. 1996). This unknown protein commonly is used as a control for cell lysis in secretion experiments. The anti-AraB serum cross-reacted with a 45-kDa cytoplasmic protein in total cell extracts from $P$. stewartii subsp. stewartii, which probably is the same as Band $\mathrm{X}$, and with a

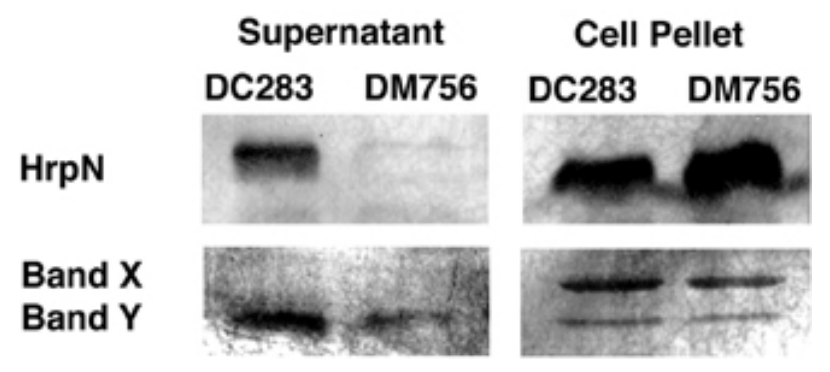

Fig. 3. Western blot of proteins from the supernatants and cell pellets of Pantoea stewartii subsp. stewartii wild-type strain DC283 and hrcC mutant DM756 reacted with antisera to $\mathrm{HrpN}_{\text {Pnss }}$ (top row) and Escherichia coli AraB (bottom row). Bands X and $\mathrm{Y}$ were used as controls for cell lysis. They are $P$. stewartii subsp. stewartii cytoplasmic and secreted proteins, respectively, which cross-react with AraB antiserum.

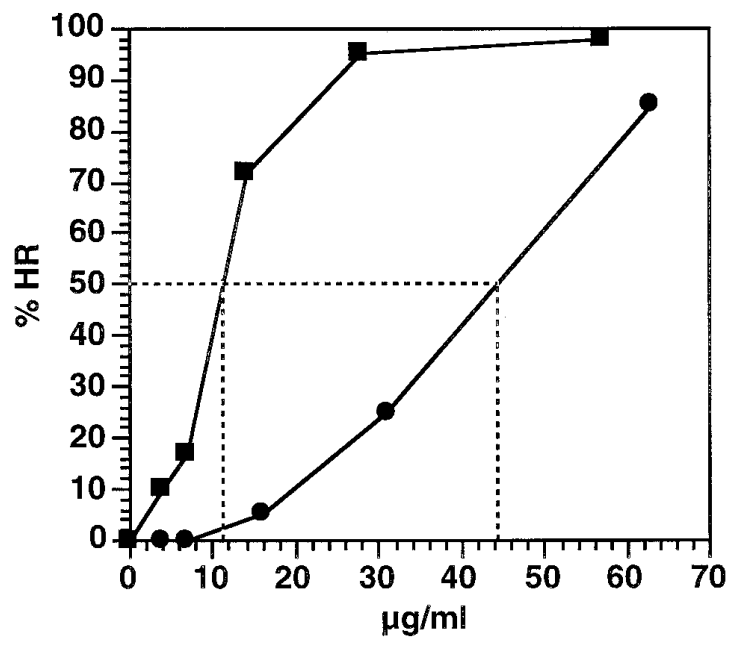

Fig. 4. Comparison of biological activities of $\mathrm{HrpN}_{\mathrm{Pnss}}$ and $\operatorname{HrpN}_{\mathrm{Ea}}$ in tobacco leaves at various dosages. Percent hypersensitive response (HR) was determined as the proportion of the infiltrated area of the leaf that developed visible necrosis at $24 \mathrm{~h}$. Each treatment was replicated on three different tobacco leaves. Standard errors were 3 to $22 \%$ for $\mathrm{HrpN}_{\mathrm{Ea}}$ and 16 to $56 \%$ for $\mathrm{HrpN}_{\text {Pnss. }}$. Percent HR for the two harpins was significantly different $(P=0.05)$ at concentrations above $10 \mu \mathrm{g} / \mathrm{ml}$. $\mathbf{\square}=$ $\mathrm{HrpN}_{\mathrm{Ea}} ;=\mathrm{HrpN}_{\text {Pnss }}$.
36-kDa protein, which we termed "Band Y." Band X was not detected in P. stewartii subsp. stewartii supernatants, whereas Band Y clearly was secreted (Fig. 3). These results indicate that almost all of the harpin present in DC283 supernatants was secreted in a hrp-dependent manner.

The CFEPs prepared from E. coli BL21(DE3/pMA2) and $E$. coli BL21(DE3/pMA1) caused a typical HR in tobacco leaves within $18 \mathrm{~h}$, whereas those prepared from $E$. coli BL21(DE3/pT7-7) and E. coli BL21(DE3/pBluescript SK) did not produce any necrosis. In a comparison of the activities of $\mathrm{HrpN}_{\mathrm{Pnss}}$ and $\mathrm{HrpN}_{\mathrm{Ea}}$ (similarly produced from BL21[DE3/pMA6]) in the same tobacco plants, $44 \mu \mathrm{g}$ of $\mathrm{HrpN}_{\text {Pnss }}$ per ml was needed to cause $50 \%$ HR but only $12 \mu \mathrm{g}$ of $\mathrm{HrpN}_{\mathrm{Ea}}$ per ml produced the same result (Fig. 4). In another independent experiment, $49 \mu \mathrm{g}$ of $\mathrm{HrpN}_{\text {Pnss }}$ per ml was needed to cause $50 \% \mathrm{HR}$ in tobacco leaf panels, whereas only $14 \mu \mathrm{g}$ of $\mathrm{HrpN}_{\mathrm{Ea}}$ per $\mathrm{ml}$ incited the same amount of necrosis. Therefore, the HR elicitor from E. amylovora was considered to be three- to fourfold more active than that from $P$. stewartii subsp. stewartii. The difference in activities between the two harpins within each experiment was statistically significant.

We also tested the effect of $\mathrm{HrpN}_{\text {Pnss }}$ and $\mathrm{HrpN}_{\mathrm{Ea}}$ on the $\mathrm{pH}$ response of tobacco suspension-cultured cells and on the cell

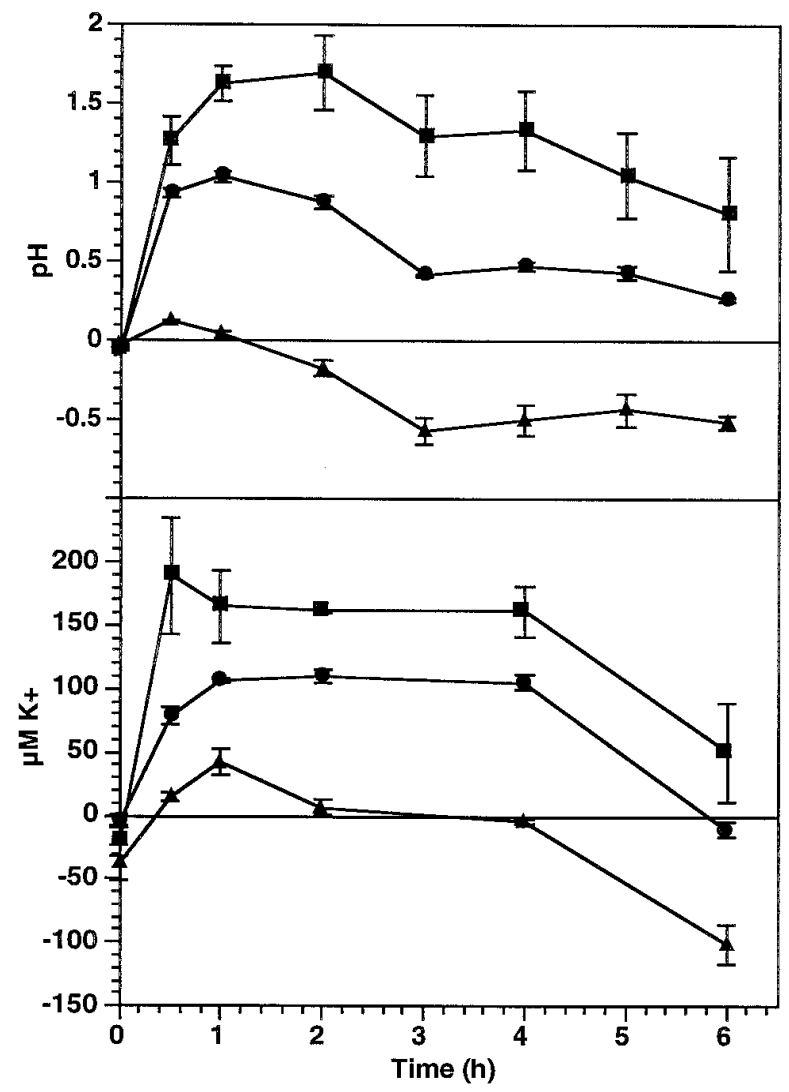

Fig. 5. Time-course of $\mathrm{pH} / \mathrm{K}^{+}$changes induced by $\mathrm{HrpN}_{\mathrm{Ea}}$ and $\mathrm{HrpN}_{\mathrm{Pns}}$ at $6 \mu \mathrm{g} / \mathrm{ml}$ and by $\mathrm{HrpN}_{\text {Pnss }}$ with $\mathrm{K} 252 \mathrm{a}$ in tobacco cell suspension cultures. At 1-h intervals, the $\mathrm{pH}$ was measured and aliquots were removed for analysis by atomic absorption spectrophotometry. The experiment was repeated once, with similar results. Buffer-treated control values were subtracted from all points. Data are means \pm standard deviation (SD). $\boldsymbol{\square}=\mathrm{HrpN}_{\mathrm{Ea}} ; \quad=\mathrm{HrpN}_{\mathrm{Pnss}} ;$ and $\boldsymbol{\Delta}=\mathrm{HrpN}_{\mathrm{Pnss}}+\mathrm{K} 252 \mathrm{a}$. 
membrane potentials of tobacco leaves. At $6 \mu \mathrm{g}$ per $\mathrm{ml}$, $\mathrm{HrpN}_{\text {Pnss }}$ and $\mathrm{HrpN}_{\mathrm{Ea}}$ induced a quick, sharp $\mathrm{pH}$ increase immediately after application to cell suspensions, with a slow decline for $2 \mathrm{~h}$ and leveling for the subsequent $3 \mathrm{~h}$ (Fig. 5). $\mathrm{HrpN}_{\mathrm{Ea}}$, however, caused higher $\mathrm{pH} / \mathrm{K}^{+}$changes than $\mathrm{HrpN}_{\text {Pnss. }}$. With $\mathrm{HrpN}_{\text {Pnss }}$ (Fig. 5) and $\mathrm{HrpN}_{\mathrm{Ea}}$ (data not shown), these responses were blocked completely by the protein kinase inhibitor $\mathrm{K} 252 \mathrm{a}$, suggesting that protein phosphorylation is required for initiation of the $\mathrm{pH}$ change. Tissue from the lowest fully expanded leaf was removed and used for membrane potential measurements. $\mathrm{HrpN}_{\mathrm{Ea}}$ produced more membrane depolarization in tobacco leaf tissue than $\mathrm{HrpN}_{\text {Pnss }}$ when tested at $20 \mu \mathrm{g}$ per $\mathrm{ml}$ (Fig. 6). $\mathrm{HrpN}_{\mathrm{Ea}}$ depolarization was faster, closer to the diffusion potential, and/or more sustained than that produced by $\mathrm{HrpN}_{\text {Pnss. }}$. When the next highest leaf on the same plant was infiltrated, $20 \mu \mathrm{g}$ of $\mathrm{HrpN}_{\mathrm{Ea}}$ per ml caused necrosis, but concentrations of up to $80 \mu \mathrm{g}$ of $\mathrm{HrpN}_{\text {Pnss }}$ per ml did not. This further suggests that, despite the high sequence homology between the two harpins, qualitative differences exist between them.

A radish bioassay (Han et al. 2000) developed previously to assess the induction of systemic resistance by bacterial biocontrol agents was used to determine whether $\operatorname{HrpN}_{\text {Pnss }}$ was able to induce systemic resistance in plants. Radish seedling roots were treated with $\mathrm{HrpN}_{\text {Pnss }}$ and 2,6-dichloroisonicotinic acid (INA), a known SAR inducer. After 7 days, the foliage was challenged by inoculation with Xanthomonas campestris pv. amoraciae strain 704b, a pathogen of radish. The leaves were then rated for severity of bacterial spot symptoms after 6 to 8 days. $\mathrm{HrpN}_{\text {Pnss }}$ treatment resulted in a $41 \%$ reduction in disease severity ratings over the inoculated control plants (Table 1). This was comparable to the amount of disease control caused by INA treatment, which resulted in a $48 \%$ reduction in disease severity.

\section{Mutagenesis of $\boldsymbol{h r p N}$.}

In the accompanying paper (Frederick et al. 2001) on the organization of the hrp-wts cluster in P. stewartii subsp. stewar-

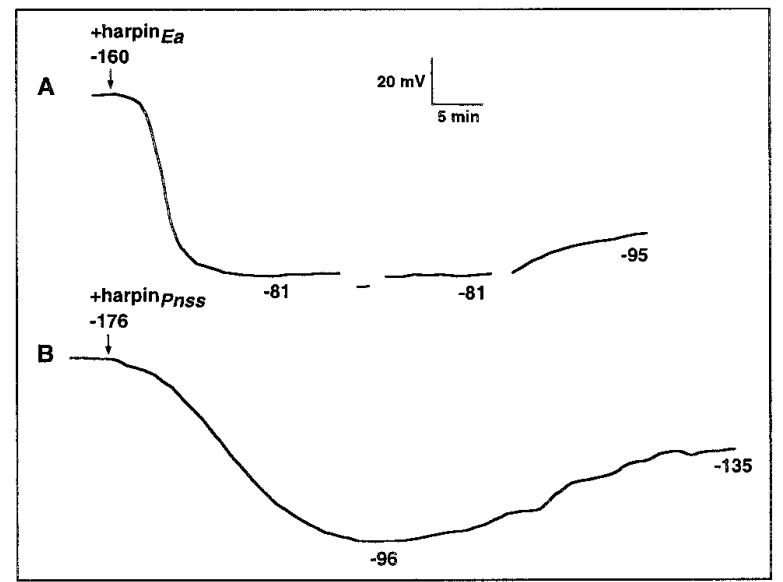

Fig. 6. Depolarization of tobacco leaf cell membrane potentials by A, $\mathrm{HrpN}_{\mathrm{Ea}}$ and $\mathbf{B}, \mathrm{HrpN}_{\mathrm{Pnss}}$. Segments were cut from the same leaf and measured in parallel. Arrow indicates the time at which the bathing solution was switched to a solution containing $20 \mu \mathrm{g}$ of $\mathrm{HrpN}_{\mathrm{Ea}}$ or $\mathrm{HrpN}_{\text {Pnss }}$ per ml. Numbers denote millivolts. Breaks are points at which a cell died and a neighboring mesophyll cell was impaled. The experiment was repeated once, with similar results. tii, we report that a single $h r p N:: \operatorname{Tn} 5$ mutant, DM760, could not elicit the HR on tobacco but was fully pathogenic on sweet corn. Although this result suggests that hrpN might not be required for pathogenesis, more $h r p N:: \operatorname{Tn} 5$ mutants were needed to decrease the possibility that the pathogenicity of DM760 was the result of the production of a truncated $\mathrm{HrpN}_{\text {Pnss }}$ molecule that was still active biologically. Two additional Tn5 insertions into $h r p N$ were isolated and marker exchanged into the genome of wild-type strain DC283 to produce strains MA1 and MA2 (Fig. 1). Marker exchange of the transposon mutations was confirmed by Southern blotting. Nucleotide sequencing placed the respective insertion mutations in DM760, MA1, and MA2 at amino acids 189, 123, and 254 of the $\mathrm{HrpN}_{\text {Pnss }}$ peptide, respectively. To discern whether the mutants might produce any truncated $\mathrm{HrpN}_{\text {Pnss }}$ proteins, the CFEPs from the mutant and wild-type strains containing pRF205 were assayed for $\mathrm{HrpN}_{\text {Pnss }}$ in Western blots (Fig. 2). The CFEPs from the mutants did not contain any cross-reacting proteins, whereas a protein ladder, typical of harpin-degradation products, was observed in the parent strain. Whereas this result suggests that truncated proteins are not produced, we do not know whether the $\mathrm{N}$ terminus of $\mathrm{HrpN}_{\text {Pnss }}$ contains any epitopes that our antiserum would recognize. In tobacco leaves, the mutants failed to elicit any necrosis at $2.5 \times 10^{8}$ cells per ml, even when hrp gene expression was increased by the introduction of pRF205 lacp-hrpS. In contrast, DC283(pRF205) caused a strong HR within $18 \mathrm{~h}$.

To complement the $h r p N$ mutants for HR elicitation, we used cosmid pES411 and a derivative thereof containing the hrpN189::Tn5 insertion, which had been used to construct DM760. The phenotype of the hrpN::Tn5 mutants, with and without the plasmids, was tested in tobacco. Panels of leaves were infiltrated with $2.5 \times 10^{8} \mathrm{CFU} / \mathrm{ml}$ of DC283(pES411), MA1(pES411), MA1(pES411 hrpN 189::Tn5), MA2(pES411), MA2(pES411 hrpN189::Tn5), DM760(pES411), and DM760 (pES411 hrpN189::Tn5). Only DC283(pES411), MA1(pES411), MA2(pES411), and DM760(pES411) produced a ne-

Table 1. Comparison of the efficacy of $\mathrm{HrpN}_{\text {Pnss }}$ and 2,6-dichloro-isonicotinic acid (INA) in the suppression of bacterial leaf spot of radish by induction of systemic resistance

\begin{tabular}{lcc}
\hline Treatment $^{\mathbf{x}}$ & $\begin{array}{c}\text { Xanthomonas campestris } \\
\text { pv. amoraciae }\end{array}$ & $\begin{array}{c}\text { Mean } \\
\text { disease severity }^{\mathbf{y}}\end{array}$ \\
\hline Control & - & 1.0 \\
Control & + & 3.9 \\
HrpN & + & 2.7 \\
INAs & + & 2.5 \\
LSD $_{0.05}{ }^{z}$ & & 0.7 \\
\hline
\end{tabular}

${ }^{x}$ Roots were treated 3 days after germination with $200 \mu$ l of autoclaved 0.25 -strength Hoagland's solution (control), with $200 \mu \mathrm{l}$ of a $50 \mu \mathrm{g} / \mathrm{ml}$ solution of INA or with $200 \mu$ of a $0.5 \mathrm{mg} / \mathrm{ml}$ solution of purified $\mathrm{HrpN}_{\text {Pnss. }}$ Plants were challenge inoculated on the foliage with a $10^{8}$ $\mathrm{CFU} / \mathrm{ml}$ suspension of $X$. campestris pv. amoraciae 7 days following treatment with the SAR-inducing agents.

y Values represent the mean disease severity ratings for two experiments. True leaves (five replicates of five plants each per experiment) were rated for disease symptoms 6-8 days following challenge inoculation with $X$. campestris pv. amoraciae. Disease scale: $1=$ symptomless; 2 = fewer than three lesions/leaf; 3 = more than three lesions/leaf, less than $25 \%$ leaf area affected by disease; $4=$ lesions covering $25-$ $50 \%$ of the leaf surface area; $5=$ lesions covering more than $50 \%$ of the leaf surface area; and $6=$ one or more leaves dead.

${ }^{\mathrm{z}}$ Least significant difference $(P=0.05)$ according to Fisher's method. 
crotic response. Likewise, when the CFEPs from the above strains were tested, only the CFEPs from the latter four strains gave a $\mathrm{HR}$ or reacted with anti-HrpN $\mathrm{N}_{\text {Pnss }}$ serum (data not shown). These results indicate that the $h r p N$ gene is required for harpin production and elicitation of the HR by P. stewartii subsp. stewartii.

\section{$\mathrm{HR}^{-}$phenotype of $\boldsymbol{h r p N}_{\text {Pnss }}$ mutants was complemented by $\operatorname{hrp} N_{E a}$. \\ Weak cross-reactions were observed between an anti-} $\mathrm{HrpN}_{\text {Pnss }}$ serum and $\mathrm{HrpN}_{\mathrm{Ea}}$ and between an anti-HrpN $\mathrm{N}_{\mathrm{Ea}}$ serum and $\mathrm{HrpN}_{\text {Pnss }}$ (data not shown). These results along with sequence homologies suggest that the two harpins might be functionally interchangeable. To test this idea, we electroporated plasmid pCPP1012, which contains hrpN from E. amylovora, into the $h r p N$ mutant MA1. This plasmid enabled MAI to cause a $\mathrm{HR}$ on tobacco at $5 \times 10^{8} \mathrm{CFU} / \mathrm{ml}$. When a CFEP from the transformant was infiltrated into tobacco leaves, it caused a strong HR in tobacco leaves within $18 \mathrm{~h}$ and reacted strongly with anti-HrpN $\mathrm{Ea}_{\mathrm{Ea}}$ serum in Western blots (data not shown). This indicates that $P$. stewartii subsp. stewartii can synthesize and secrete a heterologous harpin.

\section{Hrp $\mathrm{N}_{\text {Pnss }}$-deficient mutants of $P$. stewartii subsp. stewartii were fully pathogenic on corn.}

The pathogenicity of mutants MA1, MA2, and DM760 on corn was compared with that of wild-type strain DC283 with respect to $50 \%$ effective dose $\left(\mathrm{ED}_{50}\right)$, disease severity, and response time. In two experiments, the average $\mathrm{ED}_{50}$ for $\mathrm{DC} 283$ was $18 \pm 2 \mathrm{CFU} /$ plant and the $\mathrm{ED}_{50}$ for DM760, MAI, and MA2 were $26 \pm 1,22 \pm 10$, and $24 \pm 5 \mathrm{CFU} /$ plant, respectively, and were not significantly different $(P=0.05)$. Disease severity ratings for DC283 and the mutants were 4.2 to $4.6 \pm$ 1.2 , whereas the rating for DM3020 $\Delta h r p$-wts was $1.1 \pm 0.4$. The differences between the mutants and wild type for disease severity ratings and response times (data not shown) likewise were not statistically significant at $P=0.05$. These results show that mutations in $h r p N$ did not affect the pathogenicity of $P$. stewartii subsp. stewartii because the mutants were neither quantitatively nor qualitatively different from the wildtype controls. To measure the ability of the $h r p N$ mutants to grow and persist in planta, 7-day-old corn seedlings were inoculated with DC283, MA1, and MA2 grown in IM (pH 5.5). Bacterial populations were determined 0 to $192 \mathrm{~h}$ after inoculation. There was not a significant difference between the wild type and mutants in their ability to grow in planta. Populations increased up to $48 \mathrm{~h}$, with doubling times of 7, 7, and $6 \mathrm{~h}$ for DC283, MA1, and MA2, respectively. They then leveled off. Similar results were obtained with DM760 in a separate study (data not shown).

\section{Host-range studies.}

P. stewartii subsp. stewartii is able to colonize a number of North American grass hosts (Poos 1940). This suggests that it is an endophyte or a minor pathogen of these grasses. Because P. stewartii subsp. stewartii does not occur in South America, it probably did not coevolve with corn and may have adapted to this host after the latter was introduced into North America. It is therefore possible that $h r p N$ is needed to colonize alternative hosts. The endophytic growth of wild-type strain DC356 and the $h r p N$ mutant MA1 was examined in grass species Sor- ghum halepense L. (Johnsongrass), Sorghum vulgare cv. Rio (Rio sorghum), Pennisetum glaucum L. (pearl millet), Sorghum vulgare cv. Atlas (Atlas sorghum), Digitaria sp. (large crabgrass), Alopecurus pratensis L. (green foxtail), Panicum virgatum L. (switch grass), Panicum capillare L. (witch grass), Triticum spelta L. (Champ spelt), Avena sativa L. (Garland oats), and Panicum miliaceum L. (broom corn millet). The average initial bacterial population was $1.2 \pm 0.6 \times$ $10^{6} \mathrm{CFU} / \mathrm{g}$. In most cases, the population remained constant or increased slightly after 15 days. The populations in Garland oats and broom corn millet, however, increased to 3 to $4 \times 10^{7}$ CFU/g after 9 days. Although many grasses supported high endophytic populations of the wild-type strain and $h r p N$ mutant $\left(>10^{5} \mathrm{CFU} / \mathrm{g}\right)$, no symptoms were observed on any of the inoculated plants. DC356 growth did not differ $(P=0.05)$ from that of MA1 in any of the hosts.

\section{Production of harpin by $\boldsymbol{P}$. stewartii subsp. indologenes.}

Three strains of $P$. stewartii subsp. indologenes (Mergaert et al. 1993), which are closely related to P. stewartii subsp. stewartii, were tested for HR elicitation and harpin production. All three strains produced a HR on tobacco, and CFEPs prepared from two of the strains produced cross-reactions with $\mathrm{HrpN}_{\text {Pnss }}$ antiserum in dot blots. The two positive strains, NCPPB 2275 and NCPPB 2280, were isolated from Pennisetum americanum and Setaria italica, respectively, and were formerly classified as E. herbicola. The negative strain NCPPB 1845, isolated from pineapple, was formerly Erwinia ananas (Mergaert et al. 1993).

\section{DISCUSSION}

$\mathrm{HrpN}_{\mathrm{Ea}}$ was the first protein shown to traffic a Hrp secretion pathway and the first bacterial protein demonstrated to elicit the HR when applied exogenously to plants (Wei et al. 1992). Even though this discovery stimulated much research on type III secretion systems and led to the commercial application of harpin as a SAR inducer (Dong et al. 1999; Strobel et al. 1996), the role of harpins in pathogenesis is still uncertain. Because they are associated with most Hrp secretion systems, they probably benefit the pathogen, otherwise they would not be so conserved. Paradoxically, except in E. amylovora, harpin does not appear to be required for pathogenicity, although in some pathogens loss of $h r p N$ or $h r p Z$ can reduce symptoms and infectivity. In most cases, purified harpins have no visible adverse effects on cells of susceptible plant hosts. They can, however, cause membrane damage and therefore could be involved in stimulating the release of nutrients from host cells. This might be essential under certain inoculation conditions or, possibly, for epiphytic growth. Another currently favored hypothesis is that harpins aid in the transfer of some effector proteins across plant-plasma membranes. Again this role is speculative because some essential, secreted Dsp/Hop proteins such as DspE in E. amylovora and E. herbicola pv. gypsophilia and WtsE in P. stewartii subsp. stewartii (Barny 1995; Bogdanove et al. 1998a; Bogdanove et al. 1998b; Frederick et al. 2001; Mor et al. 2001) seem to function well, without the aid of harpins. Therefore, either harpin is purely optional, or else these bacteria have other harpin-like proteins that serve the same function. The role of harpins in the elicitation of the nonhost HR is likewise unclear. Alfano et 
al. (1996) questioned whether sufficient $H_{r p Z} Z_{\text {Pss }}$ is secreted into the apoplast by $P$. syringae pv. syringae to cause visible symptoms in nonhosts. Consequently, the necrosis obtained with this purified harpin may be the result of testing abnormally high concentrations. This raises the question as to whether the typical HR test in tobacco, which is used to identify plant-pathogenic bacteria, might sometimes be an artifact if one tests very high bacterial concentrations or grows inocula in apoplast-mimicking media to overexpress harpin, as we need to do with $P$. stewartii subsp. stewartii. Again, the fact that the loss of harpin frequently eliminates or reduces the HR could mean either that it acts as a major elicitor or it is required specifically for the delivery of yet unknown Avr proteins that are recognized by tobacco.

Sequencing the hrp-wts cluster in P. stewartii subsp. stewartii revealed a $h r p N$ gene located between the secretion and Dsp/Wts regions (Frederick et al. 2001). The predicted product of this gene is rich in glycine, lacks cysteine, and does not have a signal peptide. The results of this study confirm that the $h r p N$ product is indeed a harpin, with properties similar to those produced by Erwinia spp. When purified, the protein was able to induce HR in tobacco and Datura spp. and was effective in inducing systemic protection in radishes to bacterial leaf spot. Antiserum to PAGE-purified $\mathrm{HrpN}_{\text {Pnss }}$ was used to detect harpin production and show that it is secreted into culture supernatants. $h r p N:: \operatorname{Tn} 5$ mutants did not produce detectable harpin and did not elicit a HR in tobacco. These mutations were not polar on downstream genes, so the fact that the hrpN mutants retained very little, if any, ability to cause the $\mathrm{HR}$ indicates that $\mathrm{HrpN}_{\text {Pnss }}$ is responsible for the majority of the elicitor activity present in cells and CFEPs in our HR assays. $\mathrm{HrpN}_{\text {Pnss }}$ production and HR elicitation could be restored by complementation with cosmid pES411, but not if it contained a $h r p N:: \operatorname{Tn} 5$ insertion, thereby confirming the association between genotype, HR phenotype, and harpin production. $\mathrm{HrpN}_{\mathrm{Ea}}$ also was able to complement the $\mathrm{HR}^{-}$phenotype of $h r p N$ mutants, indicating that the two harpins are functionally equivalent. In addition, the anti-HrpN $\mathrm{N}_{\text {Pnss }}$ serum cross-reacted with HrpN from E. amylovora, P. stewartii subsp. indologenes, and E. herbicola pv. gypsophilia (Mor et al. 2001).

$P$. stewartii subsp. stewartii and other Pantoea spp. do not elicit the HR in tobacco if inoculum is grown on rich medium. This could be because i) bacterial cells die quickly after infiltration into tobacco tissue, ii) $\mathrm{HrpN}_{\text {Pnss }}$ is unstable in tobacco tissue, iii) hrp genes are expressed poorly in tobacco, iv) or $\mathrm{HrpN}_{\text {Pnss }}$ is less active on tobacco than other harpins. Failure of the bacteria to grow is probably not a factor because populations in tobacco remained above $5 \times 10^{7} \mathrm{CFU} / \mathrm{g}$ for at least $12 \mathrm{~h}$, which is a sufficient cell concentration and time for most pathogens to elicit the HR. Because preinduced cells did cause the HR, it is not likely that $\operatorname{HrpN}_{\text {Pnss }}$ is especially unstable in tobacco. Therefore, inadequate $h r p$ gene expression and lower biological activity are the most likely explanations. When a constitutive $\mathrm{HrpS}$ plasmid was used to increase hrp gene expression and boost $\mathrm{HrpN}_{\text {Pnss }}$ production, it enabled P. stewartii subsp. stewartii to cause the HR in tobacco. We also showed that $\mathrm{HrpN}_{\text {Pnss }}$ has three- to fourfold less biological activity than $\mathrm{HrpN}_{\mathrm{Ea}}$ in tobacco necrosis assays and equivalent concentrations of $\mathrm{HrpN}_{\text {Pnss }}$ are considerably less effective in causing membrane depolarization in tobacco leaf segments and $\mathrm{pH} / \mathrm{K}^{+}$changes in the supernatants of tobacco suspension- cultured cells than $\mathrm{HrpN}_{\mathrm{Ea}}$. Therefore, it will be interesting to compare hrp gene expression in corn and tobacco, test the effects of $\mathrm{HrpN}_{\text {Pnss }}$ on corn cells, and learn whether P. stewartii subsp. stewartii could induce the HR in tobacco if the hrp genes are expressed at the same level as they are in corn.

Often the loss of an $a v r$ gene results in very subtle effects on pathogenicity that can be detected only by the use of low inoculum concentrations, certain hosts, or natural entry routes. For this reason, we carefully measured the effects of $h r p N$ mutations on the virulence and infectivity of $P$. stewartii subsp. stewartii with a number of different evaluation criteria, inoculation techniques, and hosts. We were still unable to show even minor effects of a $h r p N$ mutation on the $\mathrm{ED}_{50}$, response time, symptom severity, or growth rate of $P$. stewartii subsp. stewartii in sweet corn and did not see any reduction in the ability of bacteria to grow endophytically in various grasses. In this respect, $P$. stewartii subsp. stewartii differs from E. amylovora. Because several domains of $\mathrm{HrpN}$ and HrpZ can elicit the HR, we attempted to show that our $h r p N:: \operatorname{Tn} 5$ mutants did not produce truncated products that might remain functional for virulence. Although we could not detect any truncated harpin fragments, we do not know whether our polyclonal antiserum recognizes the $\mathrm{N}$ terminus of $\mathrm{HrpN}_{\text {Pnss, }}$, thus this remains a possibility. It is more likely that the action mechanism of harpin in compatible interactions is very different from that by which it induces a HR in tobacco. Therefore, intact $\mathrm{HrpN}_{\text {Pnss }}$ would probably be needed in corn if, in fact, it is required at all for pathogenicity of $P$. stewartii subsp. stewartii on that host. Consequently, the results of this study indicate that $\mathrm{HrpN}_{\text {Pnss }}$ has a very minor role, if any, in the virulence of $P$. stewartii subsp. stewartii to sweet corn and maize and is not required to deliver essential Dsp/Hop proteins such as WtsE to host cells. Only one other harpin has been described for another member of the Pantoea group (Mor et al. 2001) and likewise is not essential for pathogenicity.

The pathogenic Pantoea spp., which most likely have evolved from endophytic "herbicola" strains by the acquisition of pathogenicity islands via horizontal gene exchange, may carry only a minimal complement of type III secretion genes and their effector proteins, in order to remain compatible with a wide range of hosts. This could be why P. stewartii subsp. stewartii does not naturally elicit the nonhost HR, and why we found very many genes for effector proteins and other harpins within the hrp-wts cluster. This study is, to our knowledge, the first assessment of the role of harpin in the virulence of a pathogen of monocots and raises the possibility that harpin may be more important in pathogenesis on dicots than on monocots. The hrp cluster in P. stewartii subsp. stewartii is very similar to that in E. herbicola pv. gyspophilae. Thus, $P$. stewartii subsp. stewartii may have received it relatively recently from a pathogen of dicots, providing a reason why $h r p N$ is still present.

\section{MATERIALS AND METHODS}

\section{Bacterial strains, plasmids, and media.}

The bacteria and plasmids used in this study are listed in Table 2. All P. stewartii subsp. stewartii strains were derived from DC283 or DC356, which are spontaneous nalidixic acid$\left(\mathrm{Nal}^{\mathrm{r}}\right)$ and rifampicin-resistant (Rif ${ }^{\mathrm{r}}$ ) mutants, respectively, of wild-type strain SS104 (Coplin et al. 1981). Culture media, 
bacterial growth, and mating conditions for P. stewartii subsp. stewartii have been described previously (Coplin 1978; Coplin et al. 1986). The following antibiotics were used in selective media, per ml: $20 \mu \mathrm{g}$ of tetracycline, $20 \mu \mathrm{g}$ of kanamycin, $100 \mu \mathrm{g}$ of ampicillin, $20 \mu \mathrm{g}$ of nalidixic acid, and $50 \mu \mathrm{g}$ of rifampicin. IM, which is optimal for the expression of hrp genes, consisted of $100 \mathrm{mM}$ 2-( $N$-morpholino)ethane-sulfonic acid (MES; Sigma Chemical, St. Louis, MO, U.S.A.), $2 \mathrm{mM}$ $\left(\mathrm{NH}_{4}\right)_{2} \mathrm{SO}_{4}, 0.1 \%$ Casamino Acids (Difco, Detroit, MI, U.S.A.), $1 \mathrm{mM}$ potassium phosphate ( $\mathrm{pH} 7.2), 1 \%$ sucrose, and $1 \mathrm{mM} \mathrm{MgSO}$. The medium was adjusted to $\mathrm{pH} 5.5$ with $\mathrm{NaOH}$ and autoclaved for $20 \mathrm{~min}$. Plasmids were mobilized from $E$. coli HB101 into P. stewartii subsp. stewartii by pRK2013::Tn7 (Coplin et al. 1986) or introduced by electroporation with a Gene Pulsar (Model 1652076; Bio-Rad Laboratories, Hercules, CA, U.S.A.) according to the manufacturer's protocol. Purified $\mathrm{HrpN}_{\mathrm{Ea}}$ and anti-HrpN $\mathrm{Ea}_{\mathrm{Ea}}$ antibodies were a gift from S. V. Beer.

\section{General DNA manipulations and sequence information.}

Plasmid DNA isolation, agarose gel electrophoresis, restriction analysis, transformation, ligation, Southern hybridization, and random primer labeling were performed according to standard protocols (Ausubel et al. 1995; Sambrook et al. 1989). Nonradioactive Southern blots were performed with the Photogene Nucleic Acid Detection System, version 2.0, as described by the manufacturer (Life Technologies, Gaithersburg, MD, U.S.A.) except that Western blue stabilized substrate for alkaline phosphatase (Promega, Madison, WI, U.S.A.) was used to detect hybridizing bands.

\section{$\operatorname{HrpN}_{\text {Pnss }}$ purification and immunoblotting.}

E. coli BL21(DE3/pMA2) cultures were grown overnight to stationary phase in $100 \mathrm{ml}$ of Terrific broth containing $200 \mu \mathrm{g}$ of ampicillin per $\mathrm{ml}$ (Sambrook et al. 1989), at $37^{\circ} \mathrm{C}$, with $0.4 \mathrm{mM}$ IPTG (Studier and Moffatt 1986). Cells were disrupted by sonication (Model MS2T; Tekmar, Cincinnati, OH, U.S.A.), with a $40 \%$ duty cycle and an output control setting of 4 , in the presence of $1 \mathrm{mM}$ PMSF. The sonicate was heated at $100^{\circ} \mathrm{C}$ for $10 \mathrm{~min}$, then centrifuged to remove the denatured proteins (Wei et al. 1992). PMSF was included in all subsequent steps and storage buffers. The resulting CFEP contained partially purified $\mathrm{HrpN}_{\text {Pnss. }}$ To further purify the $\mathrm{HrpN}_{\text {Pnss }}$ for antibody preparation, the CFEP was separated on $8 \%$ preparative SDS-PAGE gels (Laemmli 1970). The 43-kDa HrpN ${ }_{\text {Pnss }}$ band was visualized with ice-cold $0.25 \mathrm{M} \mathrm{KCl}$ (Hager and Burgess 1980). The protein was electroeluted from gel slices for $4 \mathrm{~h}$ at $200 \mathrm{~V}$ in Tris-glycine-SDS buffer ( $25 \mathrm{mM}$ Tris, $\mathrm{pH}$ 8.3; $192 \mathrm{mM}$ glycine; and 0.1\% SDS) with an Elutrap apparatus (Schleicher \& Schull, Keene, NH, U.S.A.). SDS was re-

Table 2. Bacterial strains and plasmids

\begin{tabular}{|c|c|c|}
\hline Bacterial strains or plasmid & Relevant characteristics $^{x}$ & Reference or source \\
\hline \multicolumn{3}{|l|}{ Pantoea stewartii subsp. stewartii } \\
\hline DC283 & SS104 Nal ${ }^{\mathrm{r}}$ & Coplin et al. 1981 \\
\hline DC356 & SS104 Rif ${ }^{\mathrm{r}}$ & Coplin et al. 1992a; Coplin et al. 1992b \\
\hline DM760 & DC283 hrpN189::Tn5 & Frederick et al. 2001 \\
\hline DM3020 & DC283 $\Delta h r p-w t s$ & Coplin et al. $1992 \mathrm{~b}$ \\
\hline MA1 & DC283 hrpN123::Tn5 & This study \\
\hline MA2 & DC283 hrpN254::Tn5 & This study \\
\hline DM711 & DC283 hrpJ79::Tn3HoHoI & Frederick et al. 1993 \\
\hline DM756 & DC283 hrcC240::Tn5 & Frederick et al. 2001 \\
\hline \multicolumn{3}{|c|}{ Pantoea stewartii subsp. indologenes } \\
\hline NCPPB 1845 & Wild type & Mergaert et al. 1993 \\
\hline NCPPB 2275 & Wild type & Mergaert et al. 1993 \\
\hline NCPPB 2280 & Wild type & Mergaert et al. 1993 \\
\hline \multicolumn{3}{|l|}{ Escherichia coli } \\
\hline HB101 & thr leu thi recA hsdR hsdM pro & Boyer and Roulland-Dussoix 1969 \\
\hline 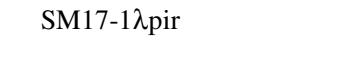 & $\begin{array}{l}\text { Apir lysogen of S17-1 thi pro recA } h s d R^{-} h s d M^{+} \mathrm{RP} 4-2-\mathrm{Tc}:: \mathrm{Mu} \\
\mathrm{Sm}^{\mathrm{r}} \mathrm{Tp}^{\mathrm{r}}\end{array}$ & Miller and Mekalanos 1988 \\
\hline BL21(DE3) & hsdS gal $\left(\lambda c I_{t s} 857\right.$ indI $\mathrm{S}_{\mathrm{am}} 7$ nin5 lacUV5-T7 gene I) & Studier and Moffatt 1986 \\
\hline \multicolumn{3}{|l|}{ Plasmids } \\
\hline pMA1 & 1.8-kb HindIII fragment in pBluescript (SK) & This study \\
\hline pMA2 & 1.8-kb HindIII fragment in pT7-7 & This study \\
\hline pMA6 & $\begin{array}{l}\text { 1.3-kb HindIII fragment from pCPP1012 containing } h r p N_{E a} \text { in } \\
\text { pBluescript (SK) }\end{array}$ & This study \\
\hline pRK2013::Tn7 & ColE1 $\mathrm{mob}^{+} \mathrm{Sm}^{\mathrm{r}} \mathrm{Sp}^{\mathrm{r}} \mathrm{Tp}^{\mathrm{r}}$ kan::Tn7 & D. Dean ${ }^{y}$ \\
\hline pDM2530 & 3-kb HindIII-BamHI $h_{r p N}{ }^{+}$fragment of pES411 in pGP704 & This study \\
\hline pCPP1012 & $\begin{array}{l}\text { 4.2-kb BamHI fragment containing } h r p N_{E a} \text { from pCPP430 in } \\
\text { pBluescript } \mathrm{KS}^{-}\end{array}$ & S. V. Beer ${ }^{\mathrm{Z}}$ \\
\hline $\mathrm{pES} 411$ & $h r p^{+}$genomic clone in pLAFR3, containing wtsF-hrpL & Coplin et al. 1986 \\
\hline pRF205 & 1.8-kb HindIII fragment containing $h r p S^{+}$in $\mathrm{pVK} 100$ & Frederick et al. 1993 \\
\hline pT7-7 & $\mathrm{T} 7$ expression vector, $\mathrm{Ap}^{\mathrm{r}}$ & Tabor and Richardson 1985 \\
\hline pBluescript & $\mathrm{Ap}^{\mathrm{r}}, \mathrm{KS}$, and $\mathrm{SK}$ & Stratagene, La Jolla, CA, U.S.A. \\
\hline pGP704 & ori $_{R 6 K} m o b_{R P 4}, \mathrm{Ap}^{\mathrm{r}}$, suicide vector & Miller and Mekalanos 1988 \\
\hline
\end{tabular}

${ }^{\mathrm{x}} \mathrm{Nal}^{\mathrm{r}}, \mathrm{Rif}^{\mathrm{r}}, \mathrm{Tc}^{\mathrm{r}}, \mathrm{Sm}^{\mathrm{r}}, \mathrm{Tp}^{\mathrm{r}}, \mathrm{Ap}^{\mathrm{r}}, \mathrm{Sp}^{\mathrm{r}}$ : resistant to nalidixic acid, rifampicin, tetracycline, streptomycin, trimethoprim, ampicillin, and spectinomycin, respectively.

y Virginia Polytechnic Institute and State University, Blacksburg, U.S.A.

${ }^{z}$ Department of Plant Pathology, Cornell University, Ithaca, NY, U.S.A. 
moved by precipitating the protein with $80 \%$ acetone at $-20^{\circ} \mathrm{C}$ (Hager and Burgess 1980) and resuspending it in $50 \mathrm{mM}$ potassium phosphate, $\mathrm{pH}$ 6.5. Protein concentration was determined according to Bradford (1976). The amount of $\mathrm{HrpN}_{\text {Pnss }}$ and $\mathrm{HrpN}_{\mathrm{Ea}}$ in the CFEPs used to compare biological activities in tobacco was quantitated by scanning the clearly visible bands of these proteins on their Coomassie blue-stained PAGE gels with a densitometer (Model GS300; Hoefer Scientific, San Francisco, CA, U.S.A.) and comparing peak heights with known amounts of purified $\mathrm{HrpN}_{\text {Pnss }}$ as a standard.

To compare the biological activities of $\mathrm{HrpN}_{\mathrm{Ea}}$ and $\mathrm{HrpN}_{\text {Pnss }}$, known amounts of the two proteins were infiltrated into panels of tobacco leaves and the proportion of the infiltrated area showing necrosis (percent HR) after $24 \mathrm{~h}$ was recorded. Each of three leaves received all dosages of both harpins in two independent experiments. These data (percent HR) were transformed to probit form, and a nonparametric Student's $t$ test was used to analyze the transformed data. Within each experiment, the amount of $\mathrm{HrpN}_{\mathrm{Ea}}$ needed to cause $50 \% \mathrm{HR}$ was compared to the amount of $\mathrm{HrpN}_{\text {Pnss }}$ needed to incite $50 \%$ necrosis in tobacco leaves.

To extract $\mathrm{HrpN}_{\mathrm{Pnss}}$ from $P$. stewartii subsp. stewartii strains containing pES411, cells were grown in $100 \mathrm{ml}$ of LB (with appropriate antibiotics), at $28^{\circ} \mathrm{C}$, to an $A_{540}$ of 0.8 . Cells were pelleted and washed in $10 \mathrm{ml}$ of IM, resuspended in $100 \mathrm{ml}$ of the same medium, and incubated, with shaking overnight. To extract from strain DC283(pRF205), the bacteria were grown overnight in $\mathrm{LB}$, at $28^{\circ} \mathrm{C}$. CFEPs were prepared as noted earlier. To obtain extracellular $\mathrm{HrpN}_{\text {Pnss }}$, culture supernatants $(200 \mathrm{ml}$ of LB) were centrifuged at $3,840 \times g$ for $10 \mathrm{~min}$, boiled for 10 min, cooled to room temperature, and mixed with an equal volume of $10 \%$ TCA. The mixture was held on ice for $15 \mathrm{~min}$ and centrifuged for $10 \mathrm{~min}$ at $20,400 \times \mathrm{g}$. The pellet was then washed with cold $70 \%$ ethanol and dissolved in $50 \mathrm{mM}$ potassium phosphate buffer ( $\mathrm{pH}$ 6.5).

For Western blotting, CFEPs were electrophoresed and electroblotted on ImmunoSelect nitrocellulose membrane (Life Technologies) (Sambrook et al. 1989). The filter was probed with anti-HrpN $\mathrm{N}_{\text {Pnss }}$ or anti-HrpN $\mathrm{N}_{\mathrm{Ea}}$ serum, and immunodetection of the bands was performed with goat anti-rabbit alkaline phosphatase-conjugated secondary antibody using a Protoblot II AP System Kit (Promega) according to the manufacturer's instructions. For dot blots, $8 \mu$ of each sample was spotted onto ImmunoSelect membranes and developed in the same way as above. Rabbit antiserum to E. coli AraB was used as a control for cell lysis in secretion experiments.

\section{Production of anti-Hrp $\mathrm{N}_{\text {Pnss }}$ antibodies.}

$\mathrm{HrpN}_{\text {Pnss }}$ antibodies were produced in two adult white New Zealand rabbits ( 3 to $4 \mathrm{~kg}$ of body weight) in response to injections with $\mathrm{HrpN}_{\text {Pnss }}$. Electroelution-purified, acetone-precipitated $\mathrm{HrpN}_{\text {Pnss }}(1.5 \mu \mathrm{g}$ per $\mu \mathrm{l})$ dissolved in $50 \mathrm{mM}$ potassium phosphate buffer, $\mathrm{pH}$ 6.5, was used for this purpose. For primary immunization, $400 \mu \mathrm{g}$ of the antigen was emulsified in $2 \mathrm{ml}$ of a 1:1 mixture of Freund's complete adjuvant and phosphate buffered saline (PBS; $137 \mathrm{mM} \mathrm{NaCl} ; 2.7 \mathrm{mM} \mathrm{KCl}$; $4.3 \mathrm{mM} \mathrm{Na}_{2} \mathrm{HPO}_{4}$; and $1.4 \mathrm{mM} \mathrm{KH}_{2} \mathrm{PO}_{4}, \mathrm{pH} 7.4$ ) and two $0.5 \mathrm{ml}$ of aliquots of the emulsion were injected subcutaneously into the hips of each rabbit. Booster injections of 200 and $100 \mu \mathrm{g}$ were administered after 4 and 6 weeks, respectively. Eight days after the second booster injection, the rabbits were bled from the marginal vein of the ear and small samples of blood were collected. Immunoglobulin $\mathrm{G}$ (IgG) titer was measured by direct enzyme-linked immunosorbent assay, and the antiserum was harvested after 8 weeks by heart puncture. To partially purify the $\mathrm{IgG}, 18 \mathrm{ml}$ of antiserum was precipitated with concentrated ammonium sulfate, resuspended in $2 \mathrm{ml}$ of PBS buffer, and dialyzed against PBS containing 0.2 mM PMSF to remove excess salt.

\section{HR assay in tobacco plants.}

Tobacco plants (Nicotiana tabacum L. cv. Wisconsin) were grown in a greenhouse and transferred to a controlled environment chamber several days before use. The chamber was maintained at $28^{\circ} \mathrm{C}, 90 \%$ relative humidity, and a cycle of $16 \mathrm{~h}$ light $-8 \mathrm{~h}$ dark. To assay for HR elicitation, bacteria were grown in Casamino Acids-peptone-glucose broth, transferred to IM liquid medium, grown for approximately $6 \mathrm{~h}$, then pelleted and resuspended in $10 \mathrm{mM}$ phosphate buffer, $\mathrm{pH} 7.0$, at a concentration of $5 \times 10^{8}$ cells per $\mathrm{ml}\left(A_{540}=0.52\right)$. Tobacco leaves were inoculated by pricking them with a dissecting needle and forcing inoculum into the wound with the open end of a 3-ml disposable plastic transfer pipette pressed against the upper leaf surface. The margins of the water-soaked infiltrated areas were marked, and the plants were rated for HR development at $24 \mathrm{~h}$. The percent HR for different strains was calculated as the proportion of the infiltrated area showing necrosis.

\section{Assay for $\mathrm{pH}$ change and $\mathrm{K}^{+}$efflux.}

Tobacco suspension-cultured cells derived from N. tabacum L. Hicks (obtained from M. Atkinson, University of Wisconsin) were maintained as described previously (Atkinson et al. 1990). Four days after transfer to fresh medium, $0.1 \mathrm{~g}$ of cells per $\mathrm{ml}$ were collected by filtration and resuspended in $5 \mathrm{ml}$ of standard assay medium (175 mM mannitol; $0.5 \mathrm{mM} \mathrm{K}_{2} \mathrm{SO}_{4}$; $0.5 \mathrm{mM} \mathrm{CaCl} 2$; and $0.5 \mathrm{mM}$ MES, adjusted to $\mathrm{pH}$ 6.0, with $\mathrm{NaOH}$ ). Cell suspensions were equilibrated in the assay medium in $30-\mathrm{ml}$ beakers at $27^{\circ} \mathrm{C}$ on a rotatory shaker at $150 \mathrm{rpm}$ for $2 \mathrm{~h}$. $\mathrm{HrpN}_{\mathrm{Ea}}$ or $\mathrm{HrpN}_{\text {Pnss }}$ (final concentration $6 \mu \mathrm{g}$ per ml) or assay medium was added to tobacco suspension cells after equilibration. $\mathrm{pH}$ measurements were recorded every hour for $6 \mathrm{~h}$ after treatment, and $200 \mu \mathrm{l}$ of aliquots were taken for $\mathrm{K}^{+}$ measurements and analyzed in an atomic absorption spectrophotometer. Two experiments with three repetitions of each treatment were performed.

\section{Electrophysiology.}

Tobacco plants (N. tabacum cv. Samsun NN) were grown under fluorescent lights $(250 \mu \mathrm{E} \times \mathrm{m} \times \mathrm{s}$; 14-h photoperiod at approximately 28 to $30^{\circ} \mathrm{C}$ ). The lowest fully expanded leaf was used for electrophysiological measurements approximately 8 to 9 weeks after planting. The next higher leaf was inoculated for symptoms, as described above. Membrane potentials were measured with glass microelectrodes in leaf segments, as described by Pavlovkin et al. (1986). At least one cell from each of two separate plants was measured in each type of treatment. Segments were placed in a Plexiglas measuring chamber and held in the darkness. The tissue was perfused continuously by gravity flow with $1 \times$ buffer $(1 \mathrm{mM} \mathrm{KCl} ; 1 \mathrm{mM}$ $\mathrm{Ca}\left[\mathrm{NO}_{3}\right]_{2} ; 0.25 \mathrm{mM} \mathrm{MgSO}$; and $\mathrm{NaH}_{2} \mathrm{PO}_{4}$ plus $\mathrm{Na}_{2} \mathrm{HPO}_{4}$ to give a $\mathrm{Na}^{+}$concentration of $1 \mathrm{mM}, \mathrm{pH}$ 5.7) (Higinbotham et al. 1964). Spongy mesophyll cells were impaled through a cut 
edge of the segments. When a stable potential had been reached, the perfusion solution was switched to one containing $\mathrm{HrpN}_{\mathrm{Ea}}$ or $\mathrm{HrpN}_{\mathrm{Pnss}}$ at a final concentration of $20 \mu \mathrm{g}$ per $\mathrm{ml}$. Measurements were performed in parallel with segments from the same leaf to reduce variability (Pike et al. 1998). Two measurements were performed with each harpin.

\section{Systemic resistance assays in radishes.}

Radish seeds (Raphanus sativus L. cv. Fuego) were grown in plastic pouches, as described by Han et al. (2000). The roots of 3-day-old seedlings were treated with $200 \mu \mathrm{l}$ of a $50 \mu \mathrm{g}$ per $\mathrm{ml}$ solution of INA or $200 \mu \mathrm{l}$ of a $0.5 \mathrm{mg}$ per ml solution of purified $\mathrm{HrpN}_{\text {Pnss. }}$ Plants were challenge inoculated on the foliage with a $10^{8} \mathrm{CFU} / \mathrm{ml}$ suspension of $X$. campestris $\mathrm{pv}$. amoraciae strain $704 \mathrm{~b}$ at 7 days following treatment with INA or $\mathrm{HrpN}_{\text {Pnss. }}$ Bacterial spot symptoms were rated, as described in Table 1.

\section{Transposon mutagenesis and marker exchange.}

E. coli S17-1 $\lambda$ pir(pDM2530) was mutagenized with $\lambda \operatorname{Tn} 5$, as described by Dolph et al. (1988). Two plasmids that had insertions in the 1.8-kb HindIII fragment were identified. Both of these plasmids were mobilized into DC283 and selected for $\mathrm{Km}^{\mathrm{r}}$. The pDM2530::Tn5 plasmid could not replicate in DC283 and integrated into the chromosome by a single crossover. Transconjugants were grown in LB-Km broth for 2 days, then plated for single colonies and screened for loss of $\mathrm{Ap}^{\mathrm{r}}$, indicating excision of the integrated plasmid.

\section{Inoculation of corn seedlings and grasses.}

Sweet corn seedlings (Z. mays L. cv. Earliking) were grown at $28^{\circ} \mathrm{C}$ and $16 \mathrm{~h}$ daylight in $50.8 \times 25.4 \times 6.35-\mathrm{cm}$ flats containing soil-vermiculite-peat moss (1:1:1). In order to assay the virulence of $P$. stewartii subsp. stewartii strains, three different inoculation procedures were used to inoculate 8-day-old seedlings with DC283 and hrpN mutants. In the "pseudostem inoculation" method, $5.0 \mu \mathrm{l}$ of inoculum (1,250 CFU/plant) were pipetted onto the cut ends of decapitated 8-day-old seedlings, and plants were rated at 10 days after inoculation on a scale of 1 to 5 : $1=$ no symptoms, $2=$ scattered lesions, $3=$ slight wilting, $4=$ severe wilt, and $5=$ dead. The data were used to calculate $\mathrm{ED}_{50}$, response time, and growth rate. $\mathrm{ED}_{50}$ values were determined graphically by plotting dose (colonyforming units) versus the probit of the proportion of the inoculated plants showing disease symptoms at 11 days after inoculation. A paired Student's $t$ test was used to analyze $\mathrm{ED}_{50}$ data, and a nonparametric Student's $t$ test was used to analyze response time data.

A number of grasses related to corn were tested for their ability to support the multiplication of wild-type strain DC356, and 11 species that supported bacterial growth to $\geq 10^{5}$ $\mathrm{CFU} / \mathrm{g}$ were selected for further study. All grasses were grown in flats, as described above. Bacterial inoculum was grown overnight in $5 \mathrm{ml}$ of $\mathrm{LB}$ at $28^{\circ} \mathrm{C}$, then pelleted and resuspended in $0.01 \mathrm{M}$ potassium phosphate buffer ( $\mathrm{pH}$ 7.2). Suspensions were adjusted to $A_{540}=0.57$. Twenty plants were inoculated for each strain-host combination. Stems were punctured with the eyelet end of a \#4 sewing needle dipped in the bacterial suspension. The eyelet held approximately $1 \mu \mathrm{l}$ of inoculum. At $0,3,9$, and 15 days after inoculation, populations of the mutant and wild-type strains were determined. Two entire plants per sample were homogenized in 5 to $20 \mathrm{ml}$ of $0.85 \%$ saline using a Tissumizer (Tekmar), and then appropriate dilutions were plated on selective media plates. Two samples per host per interval were taken, and CFU/g of fresh weight was determined. The population dynamics of the wild-type strain DC356, MA1, and MA2 at different time intervals for each experiment were compared with a paired Student's $t$ test $\left(\mathrm{n}_{1}+\mathrm{n}_{2}-3\right.$ degrees of freedom; $\left.P=0.05\right)$.

\section{ACKNOWLEDGMENTS}

We are grateful to D. Y. Han for performing the radish assays, S. Miller for assistance in antibody preparation, M. Merighi for critical reading of the manuscript, and E. Stover and L. Try for technical assistance. We thank S. V. Beer (Cornell University), Z.-M. Wei, and D. Bauer for materials and helpful advice; E. Regnier for grass seeds; and R. Dalbey (Department of Chemistry, The Ohio State University) for AraB antiserum. Salaries and research support were provided by grant US-2816-96 from the United States-Israel Binational Agricultural Research and Development Fund and by state and federal funds appropriated to the Ohio Agricultural Research and Development Center, The Ohio State University.

\section{LITERATURE CITED}

Alfano, J. R., and Collmer, A. 1997. The type III (Hrp) secretion pathway of plant pathogenic bacteria: Trafficking harpins, Avr proteins, and death. J. Bacteriol. 179:5655-5662.

Alfano, J. R., Bauer, D. W., Milos, T. M., and Collmer, A. 1996. Analysis of the role of the Pseudomonas syringae pv. syringae HrpZ harpin in elicitation of the hypersensitive response in tobacco using functionally non-polar $h r p Z$ deletion mutations, truncated HrpZ fragments, and hrmA mutations. Mol. Microbiol. 19:715-728.

Arlat, M., Van Gijsegem, F., Huet, J. C., Pernollet, J. C., and Boucher, C. A. 1994. PopA1, a protein which induces a hypersensitivity-like response on specific petunia genotypes, is secreted via the Hrp pathway of Pseudomonas solanacearum. EMBO J. 13:543-553.

Atkinson, M. M., Keppler, L. D., Orlandi, E. W., Baker, C. J., and Mischke, C. F. 1990. Involvement of plasma membrane calcium influx in bacterial induction of the $\mathrm{K}^{+} / \mathrm{H}^{+}$and hypersensitive responses in tobacco. Plant Physiol. 92:215-221.

Ausubel, F. M., Brent, R., Kingston, R. E., Moore, D. D., Seidman, J. G., Smith, J. A., and Struhl, K. 1995. Current Protocols in Molecular Biology. John Wiley \& Sons, New York.

Barny, M. A. 1995. Erwinia amylovora hrpN mutants, blocked in harpin synthesis, expressed a reduced virulence on host plants and elicit variable hypersensitive reactions on tobacco. Eur. J. Plant Pathol. 101: 333-340.

Bauer, D. W., Bogdanove, A. J., Beer, S. V., and Collmer, A. 1994. Erwinia chrysanthemi hrp genes and their involvement in soft rot pathogenesis and elicitation of the hypersensitive response. Mol. PlantMicrobe Interact. 7:573-581.

Bauer, D. W., Wei, Z.-M., Beer, S. V., and Collmer, A. 1995. Erwinia chrysanthemi harpin $\operatorname{Ech}_{\text {: }}$ : An elicitor of the hypersensitive response that contributes to soft-rot pathogenesis. Mol. Plant-Microbe Interact. 8: 484-491.

Bogdanove, A. J., Bauer, D. W., and Beer, S. V. 1998a. Erwinia amylovora secretes DspE, a pathogenicity factor and functional AvrE homolog, through the Hrp (type III secretion) pathway. J. Bacteriol. 180: 2244-2247.

Bogdanove, A. J., Kim, J. F., Wei, Z., Kolchinsky, P., Charkowski, A. O. Conlin, A. K., Collmer, A., and Beer, S. V. 1998b. Homology and functional similarity of an hrp-linked pathogenicity locus, $d s p E F$, of Erwinia amylovora and the avirulence locus avrE of Pseudomonas syringae pathovar tomato. Proc. Natl. Acad. Sci. USA 95:1325-1330.

Boyer, H. W., and Roulland-Dussoix, D. 1969. A complementation analysis of the restriction and modification of DNA in Escherichia coli. J. Mol. Biol. 41:459-472.

Bradford, M. 1976. A rapid and sensitive method for the quantitation of microgram quantities of protein utilizing the principles of proteindye-binding. Anal. Biochem. 92:248-254. 
Brown, I. R., Mansfield, J. W., Taira, S., Roine, E., and Romantschuk, M. 2001. Immunocytochemical localization of HrpA and HrpZ supports a role for the Hrp pilus in the transfer of effector proteins from Pseudomonas syringae pv. tomato across the host plant cell wall. Mol. Plant-Microbe Interact. 14:394-404.

Charkowski, A. O., Alfano, J. R., Preston, G., Yuan, J., He, S. Y., and Collmer, A. 1998. The Pseudomonas syringae pv. tomato HrpW protein has domains similar to harpins and pectate lyases and can elicit the plant hypersensitive response and bind to pectate. J. Bacteriol. 180:5211-5217.

Chen, C., Lin, H., Ger, M., Chow, D., and Feng, T. 2000. cDNA cloning and characterization of a plant protein that may be associated with the harpin $_{\text {Pss }}$-mediated hypersensitive response. Plant Mol. Biol. 43:429438.

Coplin, D. L. 1978. Properties of F and P group plasmids in Erwinia stewartii. Phytopathology 68:1637-1643.

Coplin, D. L., Rowan, R. G., Chisholm, D. A., and Whitmoyer, R. E. 1981. Characterization of plasmids in Erwinia stewartii. Appl. Environ. Microbiol. 42:599-604.

Coplin, D. L., Frederick, R. D., Majerczak, D. R., and Haas, E. S. 1986. Molecular cloning of virulence genes from Erwinia stewartii. J. Bacteriol. 168:619-623.

Coplin, D. L., Frederick, R. D., and Majerczak, D. R. 1992a. New pathogenicity loci in Erwinia stewartii identified by random Tn5 mutagenesis and molecular cloning. Mol. Plant-Microbe Interact. 5: 266-268.

Coplin, D. L., Frederick, R. D., Majerczak, D. R., and Tuttle, L. D. 1992b. Characterization of a gene cluster that specifies pathogenicity in Erwinia stewartii. Mol. Plant-Microbe Interact. 5:81-88.

Cui, Y., Madi, L., Mukherjee, A., Dumenyo, C. K., and Chatterjee, A. K. 1996. The RsmA ${ }^{-}$mutants of Erwinia carotovora subsp. carotovora strain Ecc71 overexpress $h r p N_{E c c}$ and elicit a hypersensitive reactionlike response in tobacco leaves. Mol. Plant-Microbe Interact. 9:565573.

De Gier, J.-W. L., Mansournia, P., Valent, Q. A., Philips, G. J., Luirink, J., and Von Heijne, G. 1996. Assembly of a cytoplasmic membrane protein in Escherichia coli is dependent on the signal recognition particle. FEBS Lett. 399:307-309.

Dolph, P. J., Majerczak, D. R., and Coplin, D. L. 1988. Characterization of a gene cluster for exopolysaccharide biosynthesis and virulence in Erwinia stewartii. J. Bacteriol. 170:865-871.

Dong, H., Delaney, T. P., Bauer, D. W., and Beer, S. V. 1999. Harpin induces disease resistance in Arabidopsis through the systemic acquired resistance pathway mediated by salicylic acid and the NIM1 gene. Plant J. 20:207-215.

Frederick, R. D., Majerczak, D. R., and Coplin, D. L. 1993. Erwinia stewartii WtsA, a positive regulator of pathogenicity gene expression, is similar to Pseudomonas syringae pv. phaseolicola HrpS. Mol. Microbiol. 9:477-485

Frederick, R. D., Ahmad, M., Majerczak, D. R., Arroyo-Rodríguez, A. S., Manulis, S., and Coplin, D. L. 2001. Genetic organization of the Pantoea stewartii subsp. stewartii hrp gene cluster and sequence analysis of the $h r p A, h r p C, h r p N$, and wtsE operons. Mol. PlantMicrobe Interact. 14:1213-1222.

Gaudriault, S., Malandrin, L., Paulin, J. P., and Barny, M. A. 1997. DspA, an essential pathogenicity factor of Erwinia amylovora showing homology with AvrE of Pseudomonas syringae, is secreted via the Hrp secretion pathway in a DspB-dependent way. Mol. Microbiol. 26:1057-1069.

Gaudriault, S., Brisset, M. N., and Barny, M. A. 1998. HrpW of Erwinia amylovora, a new Hrp-secreted protein. FEBS Lett. 428:224-228.

Gueneron, M., Timmers, A. C., Boucher, C., and Arlat, M. 2000. Two novel proteins, PopB, which has functional nuclear localization signals, and PopC, which has a large leucine-rich repeat domain, are secreted through the hrp-secretion apparatus of Ralstonia solanacearum. Mol. Microbiol. 36:261-277.

Hager, D. A., and Burgess, R. R. 1980. Elution of proteins from sodium dodecyl sulfate-polyacrylamide gels, removal of SDS, and renaturation of enzymatic activity: Results with sigma subunit of E. coli RNA polymerase, wheat germ DNA topisomerase, and other enzymes. Anal. Biochem. 109:76-86.

Han, D. Y., Coplin, D. L., Bauer, W. D., and Hoitink, H. A. J. 2000. A rapid bioassay for screening rhizosphere microorganisms for their ability to induce systemic resistance. Phytopathology 90:327-332.
He, S. Y. 1998. Type III protein secretion systems in plant and animal pathogenic bacteria. Annu. Rev. Phytopathol. 36:363-392.

He, S. Y., Huang, H. C., and Collmer, A. 1993. Pseudomonas syringae pv. syringae harpin ${ }_{\mathrm{Pss}}$ : A protein that is secreted via the Hrp pathway and elicits the hypersensitive response in plants. Cell 73:1255-1266.

Higinbotham, N., Etherton, B., and Foster, R. J. 1964. Effect of external $\mathrm{K}, \mathrm{NH}_{4}, \mathrm{Na}, \mathrm{Ca}, \mathrm{Mg}$ and $\mathrm{H}$ ions on the cell transmembrane electropotential of Avena coleoptiles. Plant Physiol. 39:196-203.

Kim, J. F., and Beer, S. V. 1998. HrpW of Erwinia amylovora, a new harpin that contains a domain homologous to pectate lyases of a distinct class. J. Bacteriol. 180:5203-5210.

Laby, R. J., and Beer, S. V. 1995. Degradation of harpin by apoplastic protease activity. (Abstr.) Phytopathology 85:1144.

Laemmli, V. K. 1970. Cleavage of structural proteins during the assembly of the head of bacteriophage T4. Nature 227:680-685.

Lee, J., Klusener, B., Tsiamis, G., Stevens, C., Neyt, C., Tampakaki, A. P., Panopoulos, N. J., Noller, J., Weiler, E. W., Cornelis, G. R., Mansfield, J. W., and Nurnberger, T. 2001. HrpZ $\mathrm{Psph}_{\text {from the plant }}$ pathogen Pseudomonas syringae pv. phaseolicola binds to lipid bilayers and forms an ion-conducting pore in vitro. Proc. Natl. Acad. Sci. USA 98:289-294.

Lindgren, P. B. 1997. The role of hrp genes during plant-bacterial interactions. Annu. Rev. Phytopathol. 35:129-152.

Loniello, A. O., Alfano, J. R., Bauer, D. W., and Collmer, A. 1995. Analysis of pathogenicity of a Pseudomonas syringae pv. syringae B728a AhrpZ::nptII mutant on bean. (Abstr.) Phytopathology $85: 1148$.

Mergaert, J., Verdonck, L., and Kersters, K. 1993. Transfer of Erwinia ananas (synonym, Erwinia uredovora) and Erwinia stewartii to the genus Pantoea emend. as Pantoea ananas (Serrano 1928) comb. novo and Pantoea stewartii (Smith 1898) comb. novo, respectively, and description of Pantoea stewartii subsp. indologenes subsp. novo. Int. J. Syst. Bacteriol. 434:162-173.

Miller, V. L., and Mekalanos, J. J. 1988. A novel suicide vector and its use in construction of insertion mutations: Osmoregulation of outer membrane proteins and virulence determinants in Vibrio cholerae requires toxR. J. Bacteriol. 170:2575-2583.

Mor, H., Manulis, S., Zuck, M., Nizan, R., Coplin, D. L., and Barash, I. 2001. Genetic organization of the hrp gene cluster and $d s p A E / B F$ operon in Erwinia herbicola pv. gypsophilae. Mol. Plant-Microbe Interact. 14:431-436.

Mudgett, M. B., and Staskawicz, B. J. 1998. Protein signaling via type III secretion pathways in phytopathogenic bacteria. Curr. Opin. Microbiol. 1:109-114.

Mudgett, M. B., and Staskawicz, B. J. 1999. Characterization of the Pseudomonas syringae pv. tomato AvrRpt2 protein: Demonstration of secretion and processing during bacterial pathogenesis. Mol. Microbiol. 32:927-941.

Mukherjee, A., Cui, Y., Liu, Y., and Chatterjee, A. K. 1997. Molecular characterization and expression of the Erwinia carotovora $h r p N_{E c c}$ gene, which encodes an elicitor of the hypersensitive reaction. Mol. Plant-Microbe Interact. 10:462-471.

Pavlovkin, J., Novacky, A., and Ullrich-Eberius, C. I. 1986. Membrane potential changes during bacteria-induced hypersensitive reaction. Physiol. Plant Pathol. 28:125-135.

Perino, C., Gaudriault, S., Vian, B., and Barny, M. A. 1999. Visualization of harpin secretion in planta during infection of apple seedlings by Erwinia amylovora. Cell Microbiol. 1:131-141.

Pike, S. M., Ádám, A. L., Pu, X.-A., Hoyos, M. E., Laby, R., Beer, S. V., and Novacky, A. 1998. Effects of Erwinia amylovora harpin on tobacco leaf cell membranes are related to leaf necrosis and electrolyte leakage and distinct from perturbations caused by inoculated E. amylovora. Physiol. Mol. Plant Pathol. 53:39-60.

Poos, F. W. 1940. Host plants harboring Aplanobacter stewartii without showing external symptoms after inoculation by Chaetocnema pulicaria. Econ. Entomol. 32:881.

Popham, P. L., Pike, S. M., and Novacky, A. 1995. The effect of harpin from Erwinia amylovora on the plasmalemma of suspension-cultured tobacco cells. Physiol. Mol. Plant Physiol. 47:39-50.

Rossier, O., Wengelnik, K., Hahn, K., and Bonas, U. 1999. The Xanthomonas Hrp type III system secretes proteins from plant and mammalian bacterial pathogens. Proc. Natl. Acad. Sci. USA 96:9368-9373.

Sambrook, J., Fritsch, E. F., and Maniatis, T. 1989. Molecular Cloning: A Laboratory Manual. Vols. 1-3. Cold Spring Harbor Press, Cold 
Spring Harbor, NY, U.S.A.

Strobel, N. E., Ji, C., Gopalan, S., Kuc, J. A., and He, S. Y. 1996. Induction of systemic acquired resistance in cucumber by Pseudomonas syringae pv. syringae $61 \mathrm{HrpZ}_{\mathrm{Pss}}$ protein. Plant J. 9:431-439.

Studier, F. W., and Moffatt, B. A. 1986. A bacteriophage T7 RNA polymerase to direct selective high-level expression of cloned genes. J. Mol. Biol. 189:113-130.

Tabor, S., and Richardson, C. C. 1985. A bacteriophage T7 RNA polymerase/promoter system for controlled exclusive expression of specific genes. Proc. Natl. Acad. Sci. USA 82:1074-1078.

Tampakaki, A. P., and Panopoulos, N. J. 2000. Elicitation of hypersensitive cell death by extracellularly targeted $\mathrm{HrpZ}_{\mathrm{Psph}}$ produced in planta. Mol. Plant-Microbe Interact.13:1366-1374.

Van Dijk, K., Fouts, D. E., Rehm, A. H., Hill, A. R., Collmer, A., and
Alfano, J. R. 1999. The Avr (effector) proteins HrmA (HopPsyA) and AvrPto are secreted in culture from Pseudomonas syringae pathovars via the Hrp (type III) protein secretion system in a temperature- and pH-sensitive manner. J. Bacteriol. 181:4790-4797.

Wei, Z. M., and Beer, S. V. 1993. HrpI of Erwinia amylovora functions in secretion of harpin and is a member of a new protein family. J. Bacteriol. 175:7958-7967.

Wei, Z. M., Laby, R. J., Zumoff, C. H., Bauer, D. W., He, S. Y., Collmer, A., and Beer, S. V. 1992. Harpin, elicitor of the hypersensitive response produced by the plant pathogen Erwinia amylovora. Science 257:85-88.

Zhu, W., MaGbanua, M. M., and White, F. F. 2000. Identification of two novel $h r p$-associated genes in the $h r p$ gene cluster of Xanthomonas oryzae pv. oryzae. J. Bacteriol. 182:1844-1853. 